\title{
In the Classroom
}

\section{Plurilingualism in Higher Education: A Collaborative Initiative for the Implementation of Plurilingual Pedagogy in an English for Academic Purposes Program at a Canadian University}

\author{
Angelica Galante, Kerstin Okubo, Christina Cole, \\ Nermine Abd Elkader, Nicola Carozza, Claire Wilkinson, \\ Charles Wotton, \& Jelena Vasic
}

Previous literature on higher education suggests the inclusion of pedagogy that is linguistically and culturally inclusive in settings with increasing multilingualism, which is the case in Canada. Yet, little is known as to how the implementation of such pedagogy can take place, particularly in language programs. This article reports a researcher-instructor collaboration that aimed at implementing plurilingual practices, such as translanguaging, plurilingual identity, comparons nos langues, and intercomprehension over 4 months in an English for Academic Purposes (EAP) program at a university in Toronto, Canada. Seven EAP instructors collaborated with a researcher to implement weekly plurilingual tasks: They conducted an environment analysis, examined the logistics of implementation, and collaboratively examined the tasks. The article presents the process of implementation of the plurilingual tasks and proposes a framework for collaboration with four key elements: administrative support, openness to the use of languages other than English in class, weekly collaborative checks with the researcher, and the learner-centered nature of the tasks. Implications for the implementation of plurilingualism in English language programs in higher education are discussed.

La littérature existante sur l'enseignement supérieur suggère l'inclusion d'une pédagogie linguistiquement et culturellement inclusive là où le multilinguisme est en hausse, ce qui est le cas au Canada. On sait toutefois peu de choses sur la façon dont la mise en cuvre d'une telle pédagogie pourrait s'effectuer, particulièrement dans les programmes de langue. Le présent article rend compte d'une collaboration entre une chercheuse et plusieurs professeurs qui portait sur la mise en œuvre de pratiques plurilingues comme le translangagisme, l'identité plurilingue, Comparons nos langues, et l'intercompréhension sur une période de 4 mois dans 
le cadre d'un cours d'anglais académique (EAP) offert dans une université de Toronto, au Canada. Sept professeurs d'anglais académique ont collaboré avec une chercheuse à la mise en cuvre de tâches plurilingues hebdomadaires, et ce, en réalisant une analyse de l'environnement, en examinant la logistique de la mise en auvre et en collaborant à l'examen des tâches. L'article présente le processus de mise en auvre des tâches plurilingues et propose un cadre de collaboration comportant quatre éléments clés : soutien administratif, ouverture à l'utilisation de langues autres que l'anglais en classe, contrôles collaboratifs hebdomadaires avec la chercheuse et choix de tâches centrées sur l'apprenante ou l'apprenant. Les implications de la mise en cuvre du plurilinguisme à l'intérieur des programmes de langue anglaise dans l'enseignement supérieur font l'objet d'une discussion.

KEYWORDS: plurilingual pedagogy, English for academic purposes, higher education, translanguaging, intercomprehension, comparons nos langues

\section{Introduction}

Canadian multilingualism is on the rise, and communities across the country are more diverse than ever before. Between 2011 and 2016, the number of people speaking more than one language at home increased $13.3 \%$, totalling 20\% of Canada's population (Statistics Canada, 2016). Recent changes, including government initiatives of immigration intake and inbound internationalization of education, have contributed to the rise of multilingualism. The number of international students in Canada has grown exponentially: There was an increase of 154\% between 2010 and 2018 (Canadian Bureau for International Education, 2018), surpassing the targeted estimate of nearly half a million by 2022 (Canada's International Education Strategy, 2014). Instructors in Canadian colleges and universities often witness a reality that has become the norm: Students from diverse linguistic and cultural backgrounds gather in the same classroom where many languages coexist, despite English being the language of instruction. Yet, while both immigration programs and inbound internationalization of education have been a priority of the Canadian government, which has certainly benefited the country's economy, these changes have posed a dilemma for postsecondary program administrators and instructors in the provision of linguistically and culturally inclusive instruction.

Typically, international students enter English-speaking postsecondary education with upper intermediate levels of English proficiency, but many of them take English for Academic Purposes (EAP) programs prior to or during the completion of their studies. These programs aim to prepare students with the linguistic and cultural knowledge of English required to meet the academic demands of higher education. For example, EAP programs prepare 
students to apply academic conventions commonly used, such as academic presentations, research-based arguments, and others. A vast majority of students attending EAP programs have graduated from high schools outside of Canada, in countries that follow academic conventions based on the local culture and in a language other than English. However, even plurilingual students who have gone through years of secondary education in Canada or studied in international schools, where the medium of instruction is English, also attend EAP programs. One main issue with these programs, however, is the focus on academic literacies based on the assumption that academic culture is relatively homogeneous (Lea \& Street, 1998), and that knowledge created by plurilingual students should conform to only one variety of English, the so-called standard, neglecting other forms of Englishes and other languages. This homogeneous assumption is erroneous as communities of practice in academia are plural (Lea, 2004), and knowledge production can take different forms. Given that diversity is inherent in EAP classroomsand, arguably, in Canadian society-postsecondary programs can greatly benefit from a differentiated pedagogy that is linguistically and culturally inclusive, which has not always been the case.

To address this pedagogical gap, we report a collaborative initiative among a researcher and seven EAP instructors - all coauthors in this articlein our attempt to initiate change by introducing plurilingual tasks in one EAP course at a university in Toronto, Canada.

\section{Plurilingualism in Higher Education}

Recent research has called for multi/plurilingual pedagogy in education in contexts with increasing multilingualism (Kubota, 2016; May, 2014; Piccardo \& Puozzo Capron, 2015; Taylor \& Snoddon, 2013). A plurilingual shift moves away from the structuralist notion of language as a set of standard norms to the use of language as symbiotically interacting to generate new meanings (Canagarajah, 2018; Piccardo, 2013). While studying in Canada, international students often make use of more than one language to perform everyday tasks such as reading an article, communicating with friends, or using online tools. These tasks may require the use of different languages and/or a mix of languages, all linguistic behaviours in which these students naturally engage. In higher education, however, pedagogical practices remain largely monolingual, neglecting the unique opportunity to turn students' spontaneous plurilingual practices into pedagogical strategies. While this article reports a collaborative initiative in an EAP program, plurilingual practices can occur in other disciplines (see Pujol-Ferran, DiSanto, Núñez Rodríguez \& Morales, 2016 for examples).

Studies in higher education have shown that recognizing and valuing students' plurilingual competence is essential for better learning. Marshall and Moore (2013), for example, examined how international students in a first- 
year academic literacy course used their plurilingual competence in a university in Vancouver, Canada; results show that international students have agency over their plurilingualism in both social and educational contexts, and make use of their linguistic repertoire as a resource to communicate, even if the language of instruction is only English. While students spontaneously use languages other than English in their academic studies, one main concern is how to support instructors with suitable materials to implement pedagogy that can harness students' plurilingual practices. In fact, Ellis (2013) investigated English as a second language (ESL) teachers' views about language teaching and learning and found that plurilingual teachers have a heightened awareness of their own plurilingual strategies but still need support to transform this knowledge into pedagogical practice. Similar results were found in another study that examined the extent to which university instructors accommodated the increasingly linguistically and culturally diverse student language profile in Australia and the United Kingdom (Pauwels, 2014): Despite being plurilingual, most instructors had either limited awareness of or interest in their students' linguistic repertoire and viewed students' plurilingual practices as an annoyance. These studies show that a shift to plurilingual pedagogy in higher education requires a systematic approach with pedagogical support for instructors, and we aimed to specifically address this need. Nevertheless, one should acknowledge limitations such as the structural monolingual constraints that operate within institutions, which may inhibit students from confidently using their plurilingual repertoire and lead them to self-regulate by using English only.

\section{Environment Analysis of the EAP Program}

Our collaboration was part of a larger research project (Galante, 2018, 2019), and this article focuses on how plurilingual pedagogy was applied in EAP. Because our collaboration aimed to introduce plurilingualism in the curriculum for the first time, we decided that the implementation would take place in one course only-the Academic Listening and Speaking (ALS) course. Given that an analysis of the environment is important prior to implementing a new curriculum (Nation \& Macalister, 2010), we examined three main factors: the situation of the EAP program, the instructors, and the students.

The Situation: The EAP program is housed in a university in Toronto, Canada. Because of the university's increasing intake of international students, the school administrator and the teaching staff were interested in providing pedagogy that is linguistically and culturally inclusive, which facilitated our collaboration. The school administrator made three important recommendations: (a) the instructors should decide the number of hours available for the implementation of the tasks; (b) the tasks would need to integrate into the existing EAP curriculum; and (c) the instructors would have the support from the administration, whether they decided to implement plurilingual peda- 
gogy or not. These three recommendations were key to allow instructors to feel supported by the school administration and voluntarily decide whether they wished to initiate the collaboration.

The Instructors: All seven instructors had been working in the EAP program for at least a year and were familiar with the needs of the program. They were all plurilingual and had studied languages other than English, and most of them spoke two or three languages. While none of them had received training in plurilingual education, they were highly experienced: Each instructor had taught ESL and/or EAP for 10 years and had a teaching certificate in ESL. Four had a master's degree in Education or Applied Linguistics, one was completing a master's degree in Education, one was a $\mathrm{PhD}$ candidate in English Literature, and one had a PhD in Second Language Education. During a 1-hr-long meeting, the instructors and the researcher made decisions related to feasibility and logistics of the implementation of linguistically and culturally inclusive pedagogy; for example, the instructors suggested that the tasks would be provided by the researcher and available in advance so that the instructors could review and provide any necessary feedback. They also decided that each task would be approximately $30-$ to $40-$ min long and would be delivered on a weekly basis, with a total of 10 weeks.

The Students: The students were part of seven intact classes, with approximately 10 to 12 students per class. They had international status, and came from Russia, Turkey, Ecuador, Taiwan, Korea, and Japan, with a vast majority of the students from China (84\%). In each class, it was common to have one or two students only who did not speak Chinese as a first language. The researcher visited the seven classes in the first week of the term to explain the collaboration with the instructors and answer any questions. The students were told that their instructors would pilot innovative tasks about important topics in Canadian culture and society. All of the students agreed to participate in receiving the tasks.

\section{Implementation of the Plurilingual Tasks}

The plurilingual tasks were inspired by six pedagogical strategies, all feeding into the plurilingual framework for language teaching: (a) drawing on the notion of linguistic repertoire (Busch, 2012, 2015), the tasks encouraged students to activate their entire plurilingual repertoire with all linguistic knowledge they had developed, including languages and dialects; (b) with a focus on pedagogy, translanguaging (Cenoz, 2017; Otheguy, García \& Reid, 2015) engaged students in actively using their repertoire, from reading information in one language and discussing it in another language to language mixing, all aimed at meaning-making; (c) comparons nos langues (Auger, 2004) required that students compare the languages in their repertoires with the target language (English), such as on syntax, semantics, and pragmatics; (d) intercultural encounters (Byram, 1997; CoE, 2009) engaged students in reflec- 
tions about cultural knowledge and aimed at raising awareness of their own assumptions, stereotypes, and preconceptions; (e) intercomprehension (Doyé \& Meissner, 2010; Melo-Pfeifer, 2014) encouraged students to use their own plurilingual repertoires to try to understand a new language, which was English in our course; and, finally, (f) plurilingual and pluricultural competence (CoE, 2018; Coste, Moore, \& Zarate, 2009) was presented to students so they could reflect on their ability of using different languages and cultural knowledge to enhance communication. The six pedagogical strategies were embedded into all 10 tasks.

A Dropbox folder with the plurilingual tasks was shared with the instructors. Every week, the researcher sent an e-mail to the instructors and asked for their feedback (if any) and made herself available in case there were questions regarding the purpose of the task or the implementation phase. These weekly checks were important to ensure that instructors felt supported by the researcher prior to and while implementing the tasks. The researcher also asked for suggestions of topics and/or language items so that the plurilingual tasks could integrate the EAP curriculum. For example, some instructors suggested tasks introducing idioms and discourse markers, items that were part of the existing curriculum. All of the tasks were validated by the instructors prior to implementation to ensure suitability for the student population and curriculum (the tasks are available at www.breakingtheinvisiblewall.com/ tasks).

\section{Collaborative Framework for Implementation of Plurilingual Pedagogy}

While we are aware that implementation of plurilingual pedagogy can take several forms, we decided to adopt a somewhat conservative approach and introduce it in the form of weekly tasks. To maintain consistency across the curriculum, the seven instructors delivered the same tasks in their classes. Most important, our collaboration involved different stakeholders, all willing to work together to initiate change in pedagogy, from an English-only to a plurilingual approach. We propose a framework with four key elements essential for successful collaboration, as illustrated in Figure 1 and explained below: 


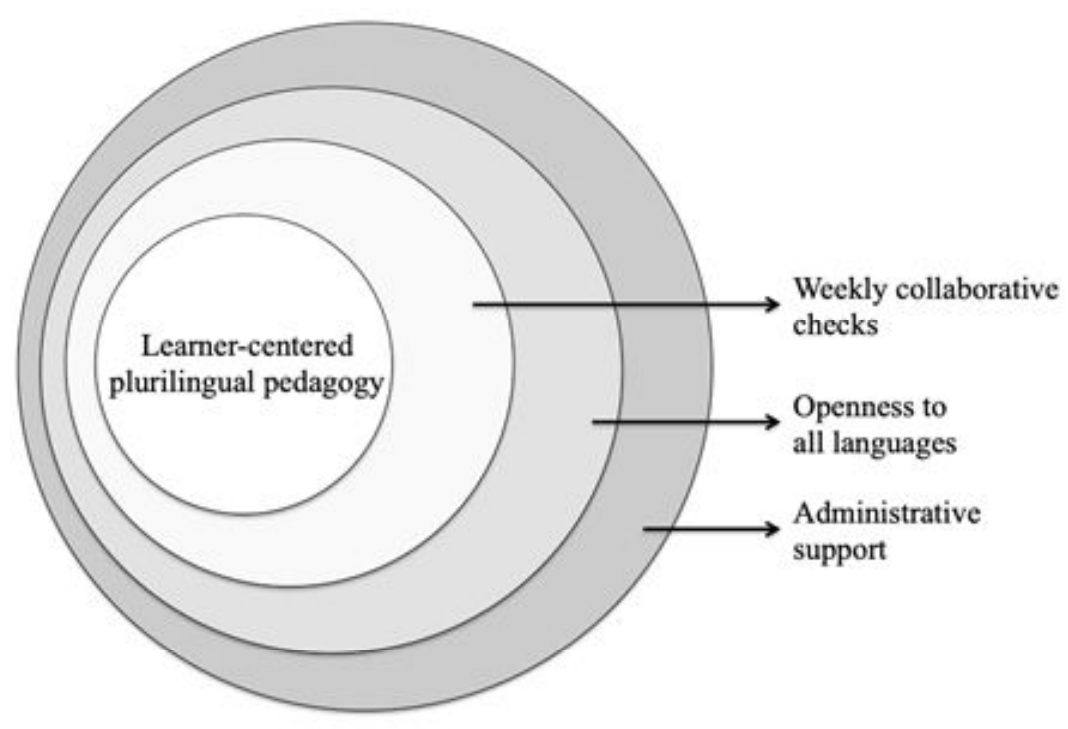

Figure 1. Collaborative Framework for Implementation of Plurilingual Pedagogy.

\section{Administrative Support}

As previously stated in the environment analysis, administrative support was key to ensure our collaboration was successful. First, the administrator required that the researcher explained to the instructors that their participation would not affect their employment status in any negative way, that is, whether they decided to participate or not, this would not pose a risk. Second, the administrator also asked that the researcher made it clear to the instructor that the success of the tasks would not depend on their teaching abilities, and that the phenomenon under investigation relied solely on the tasks. Third, the administrator shared our view that linguistically and culturally relevant pedagogy could enhance the EAP program, which facilitated the process of implementation. Finally, through the 4 months of the project, the administrator ensured assistance with logistics, such as room booking, equipment, and access to the instructors' office space, classroom, and school facilities.

\section{Openness to All Languages}

Any instructor who is willing to implement a plurilingual approach in an EAP program should be open to their students' use of languages other than English in the classroom. During the completion of the tasks, all of the students reported that they spoke at least two languages, English and their first language, and many students had knowledge of other languages and dialects, even if partial. Because $84 \%$ of our student population was from China, we hypothesized that non-Chinese students might feel excluded from conversations when these were done in languages other than English; however, students were encouraged to draw on their entire repertoire. Many of our Chinese students knew languages other than English such as Korean, 
Japanese, French, and Spanish. Similarly, Ecuadorian students also knew more than Spanish (first language or L1) and English (second language or L2 and sometimes third language or L3 or fourth language or L4), and expressed interest in learning Chinese. In class, it was common for students from different L1 backgrounds to find out that they had learned a language because of their shared interest: One example is a Chinese student and an Ecuadorian student who had learned Korean because of their interest in K-pop and Korean drama, and Japanese because of their interest in reading mangas. Contrary to what we had anticipated, having a Chinese-speaking dominated classroom was not an issue in terms of engagement with plurilingual practices, and students, regardless of their L1 background, felt included in the tasks.

Because the ALS course had a focus on listening and speaking skills, most of the tasks included oral discussions in which students needed to attentively listen to one another. The use of languages other than English was not only allowed but purposefully required so that students could realize the pedagogical potential of using translanguaging and comparons nos langues to learn academic English. In some instances, we asked students to speak in other languages in front of the class and explain differences and similarities across languages while other times, we asked students to read a text in a language they may not necessarily have learned formally and try to use their plurilingual repertoire to understand the main message (intercomprehension). Because all of the 10 tasks had a pedagogical purpose for language learning, there was no concern about having to maintain a strict English-only environment; however, the target language of the EAP program is English, and students were still required to perform only in English in their assignments.

\section{Weekly Collaborative Checks with the Researcher}

It is important to note that the researcher had initially informed the instructors that the project was seeking to investigate both affordances and challenges of the plurilingual tasks and not whether instructors would apply the tasks correctly. In addition, the researcher shared the responsibility of the implementation process as she took on the work of designing the tasks; this setup allowed instructors to feel supported, as they were not the ones being judged.

Admittedly, our collaboration had some limitations. Logistically, the provision of professional development in plurilingualism prior to implementation was unfeasible. To address this limitation, the researcher made herself available in three different manners: in person, via e-mail, and via an online forum. In person, the researcher visited the EAP program on a weekly basis and informally talked to instructors about the implementation of the tasks. These conversations took place only if the instructors initiated the discussion as the researcher's role was not to check what instructors were doing. 
Via e-mail, the researcher sent one message per week to inform that the task for that week had been uploaded to their Dropbox folder and to ask the instructors if they had any questions or suggestions for modifications. Rather than suggesting modifications, some instructors asked if future tasks could be designed based on topics they had suggested; the researcher designed two tasks (Task 5 and Task 7) based on their suggestions. Finally, an online forum was set up so instructors could enter their thoughts about the tasks and share any success or unsuccessful stories with other instructors and the researcher. Sharing experiences in the online forum was helpful to mitigate any issues, although accounts were mostly positive. All these supportive measures ensured a seamless collaboration between the researcher and the instructors.

\section{The Learner-Centred Nature of the Tasks}

The tasks aimed at students' lived experiences with languages and cultures, with students given an active role as agents of their own learning. We often started a task delivery by activating students' schemata, relating topic and content to their own experiences and allowing for an individualized process. For example, in one task about discourse markers (Task 7), we first asked students if discourse markers were used in other languages and whether their use was similar to or different than English: Students tapped into their repertoires, translanguaged during class discussions, and engaged in comparons nos langues by writing sentences in languages other than English on the board and analyzing the position of the discourse marker in the sentences (syntax) and its meaning (semantics). While the target language was still English, the plurilingual tasks allowed students to engage in a process of cross-linguistic analysis, raising awareness of both linguistic and social dimensions of language use. Ultimately, our aim was to raise students' awareness that their linguistic repertoire is a rich resource for learning any language, including English.

\section{Conclusion and Implications for Future Implementation}

The provision of linguistically and culturally responsive pedagogy in increasing multilingual settings is timely (Piccardo \& Puozzo Capron, 2015), and we aimed to fill in this gap by implementing plurilingual tasks in an EAP program at a Canadian university. In this article, we described the manner of implementation, the tasks, and the process of collaboration between the researcher and seven instructors. We proposed a framework for collaboration with four key elements that contributed to the success of the collaboration: administrative support, instructors' openness to the use of languages other than English in class, weekly collaboration checks, and the learner-centred nature of the tasks. While we recognize that our implementation was somewhat conservative-introducing plurilingual tasks in one course only rather 
than infusing plurilingualism in the entire EAP curriculum - it had little disruption and carefully initiated the process of shifting pedagogy from English-only to more linguistically and culturally inclusive practices. Plurilingual pedagogy in higher education can take several forms, and we argue that prior to implementing language tasks, an analysis of the environment is needed.

Besides the four elements for successful collaboration outlined in Figure 1, we make three other recommendations, which could be applied to both EAP and ESL programs in higher education. First, the descriptors of plurilingual and pluricultural competence, recently published in the companion volume of the Common European Framework of Reference for Languages (CEFR-Council of Europe, 2018), can serve as a guide for language teaching, learning, and assessment. For example, course designers and instructors can make use of these descriptors to establish teaching and learning goals. Clearly, these descriptors are not meant to be used top-down, and instructors will need to carry out a critical analysis of the context to assess the suitability of the descriptor in their particular setting and if any change is necessary. Second, to initiate a process in shifting pedagogy, we recommend that the plurilingual tasks be gradually introduced in the language program and that collaboration between instructors and administrators be set up. Rather than designing new language tasks based on plurilingual pedagogy, instructors can make use of existing materials and adapt them by introducing one or more plurilingual strategies such as intercomprehension, comparons nos langues, and translanguaging. Not all of the tasks need to make use of these strategies but a balance of plurilingual versus nonplurilingual tasks could be a good start. The gradual introduction of plurilingual pedagogy will allow instructors and students to be familiar with the shift prior to its implementation across the entire program. We argue, however, that plurilingual tasks should not be considered as a token for diversity in the classroom but become a common practice across the curriculum.

We conclude by encouraging language instructors and program directors in higher education to initiate a gradual shift from an English-only to a plurilingual approach and work collaboratively as, ultimately, students are the ones who will benefit the most.

\section{Acknowledgements}

Portions of this article were presented at the 2017 Teaching English as a second language (TESL) Canada conference and the 2018 Teaching English to Speakers of Other Languages (TESOL) conference. This study was made possible through an Ontario Graduate Scholarship, a Doctoral grant from the Social Sciences and Humanities Research Council of Canada (752-2016-1063), a Doctoral Dissertation grant from The International Research Foundation (TIRF) for English Language Education, and a Senior Doctoral fellowship from the International Foundation Program at New College/University of Toronto. We would like to thank Bruce Russell and Katherine Anderson for their support, and all the students who participated in the study. 


\section{The Authors}

Angelica Galante is an assistant professor in Second Language Education with a focus on Plurilingualism at McGill University. She conducts research in the area of language learning and pedagogy at Plurilingual Lab, mcgill.ca/plurilinguallab.

Kerstin Okubo has been an ESL instructor for 20 years. She is currently the lead instructor for Academic Listening and Speaking at the University of Toronto's International Foundation Program at New College.

Christina Cole has an MA in Applied Linguistics, an MA in English Literature, and a PhD (ABD) in English Literature. She has taught ESL for more than 10 years and currently teaches Academic Listening and Speaking at the University of Toronto's International Foundation Program at New College.

Nermine Abd Elkader holds an MA in TESL and a PhD in Education with a focus on multiculturalism. She has taught in Egypt, the United States, and in Canada and currently teaches Academic Listening and Speaking at the University of Toronto's International Foundation Program at New College.

Nicola Carozza holds a Master of Teaching degree and is the editor of the TESL Ontario Contact Magazine. He has taught in China and Canada and currently teaches Critical Reading and Writing at the University of Toronto's International Foundation Program at New College.

Claire Wilkinson holds an MA in Education. She has been an ESL instructor for more than 15 years and has taught in Japan, Turkey, and Chile. She currently teaches Academic Listening and Speaking at the University of Toronto's International Foundation Program at New College.

Charles Wotton holds an MA in Applied Linguistics. He has been an ESL instructor for more than 20 years and has taught in Spain, Russia, and Canada. He currently teaches Academic Listening and Speaking at the University of Toronto's International Foundation Program at New College.

Jelena Vasic holds an MEd in Adult Education and Community Development. She has been an ESL instructor for more than 10 years and has taught in South Korea, the Philippines, and Canada. She currently teaches Academic Listening and Speaking at the University of Toronto's International Foundation Program at New College. Her creative research projects can be seen at https://www.metamorphosisthroughmovement.com.

\section{References}

Auger, N. (2004). Comparons nos langues. Démarche d'apprentissage du français auprès d'enfants nouvellement arrivés (ENA). Languedoc-Roussillon, France: CRDP. Retrieved from http://asl. univ-montp3.fr/masterFLE/n.auer/Livret_Comparons.pdf

Busch, B. (2012). The linguistic repertoire revisited. Applied Linguistics, 33(5), 503-523. doi: 10.1093/applin/ams056

Busch, B. (2015). Expanding the notion of the linguistic repertoire: On the concept of Spracherleben-the lived experience. Applied Linguistics, 36(4), 1-20. doi: 10.1093/applin/ amv030

Byram, M. (1997). Teaching and assessing intercultural communicative competence. Clevedon, UK: Multilingual Matters.

Canada's International Education Strategy. (2014). Harnessing our knowledge advantage to drive innovation and prosperity. Retrieved from http://international.gc.ca/global-markets-marchesmondiaux/education/strategy-strategie.aspx?lang=eng

Canadian Bureau for International Education (2018). International students in Canada. Retrieved from https://cbie.ca/infographic/

Canagarajah. S. (2018). Translingual practice as spatial repertoires: Expanding the paradigm beyond structuralist orientations. Applied Linguistics, 39(1), 31-54. doi: 10.1093/applin/amx041 
Cenoz, J. (2017). Translanguaging in school contexts: International perspectives. Journal of Language and Identity, 16(4), 193-198. doi: 10.1080/15348458.2017.1327816

Coste, D., Moore, D., \& Zarate, G. (2009). Plurilingual and pluricultural competence: Studies towards a Common European Framework of Reference for language learning and teaching. Strasbourg, France: Council of Europe Publishing. Retrieved from https://www.coe.int/t/dg4/linguistic/ Source/SourcePublications/CompetencePlurilingue09web_en.pdf

Council of Europe. (2009). Autobiography of intercultural encounters. Retrieved from https://rm.coe. int/autobiography-of-intercultural-encounters/16806bf02d

Council of Europe. (2018). Common European Framework of Reference for Languages: Learning, teaching, assessment. Companion volume with new descriptors. Strasbourg, France: Council of Europe Publishing. Retrieved from https://rm.coe.int/cefr-companion-volume-with-newdescriptors-2018/1680787989

Doyé. P., \& Meissner, J.-F. (Eds.). (2010). Lernerautonomie durch Interkomprehension: Projekte und Perspektiven. Tübingen, Germany: Narr.

Ellis, E. (2013). The ESL teacher as plurilingual: An Australian perspective. TESOL Quarterly, 47(3), 446-471. doi: 10.1002/tesq.120

Galante, A. (2019). "The moment I realized I am plurilingual": Plurilingual tasks for creative representations in EAP at a Canadian university. Applied Linguistics Review. Advance online publication. doi: 10.1515/applirev-2018-0116

Galante, A. (2018). Plurilingual or monolingual? A mixed methods study investigating plurilingual instruction in an EAP program at a Canadian university (Doctoral dissertation, University of Toronto, Canada). Retrieved from http://hdl.handle.net/1807/91806

Kubota, R. (2016). The multi/plural turn, postcolonial theory, and neoliberal multiculturalism: Complicities and implications for applied linguistics. Applied Linguistics, 37(4) 474-494. doi: 10.1093/applin/amu045

Lea, M. R. (2004). Academic literacies: A pedagogy of course design. Studies in Higher Education, 29(6), 739-756. doi: 10.1080/0307507042000287230

Lea, M. R., \& Street, B. V. (1998). Student writing in higher education: An academic literacies approach. Studies in Higher Education, 23(2), 157-172. doi: 10.1080/03075079812331380364

Marshall, S. \& Moore, D. (2013). 2B or not 2B plurilingual: Navigating languages literacies, and plurilingual competence in postsecondary education in Canada. TESOL Quarterly, 47(3), 472-499. doi: 10.1002/tesq.111

May, S. (Ed.). (2014). The multilingual turn: Implications for SLA, TESOL and bilingual education. New York, NY: Routledge.

Melo-Pfeifer, S. (2014). Intercomprehension between Romance Languages and the role of English: A study of multilingual chat rooms. International Journal of Multilingualism, 11(1), 120-137. doi: 10.1080/14790718.2012.679276

Nation, I. S. P., \& Macalister, J. (2010). Language curriculum design. New York, NY: Routledge.

Otheguy, R., García, O., \& Reid, W. (2015). Clarifying translanguaging and deconstructing named languages: A perspective from linguistics. Applied Linguistics Review, 6, 281-307. doi: 10.1515/applirev-2015-0014

Pauwels, A. (2014). The teaching of languages at university in the context of super-diversity. International Journal of Multilingualism, 11(3), 307-319. doi: 10.1080/14790718.2014.921177

Piccardo, E. (2013). Plurilingualism and curriculum design: Towards a synergic vision. TESOL Quarterly, 47(3), 600-614. doi: 10.1002/tesq.110

Piccardo, E., \& Puozzo Capron, I. (2015). Introduction. The Canadian Modern Language Review/La revue canadienne des langues vivantes, 71(4), 317-323. University of Toronto Press. Retrieved August 3, 2019, from Project MUSE database.

Pujol-Ferran, M., DiSanto, J. M., Núñez Rodríguez, N., Morales, A. (2016). Exploring plurilingual pedagogies across the college curriculum. The Canadian Modern Language Review/La revue canadienne des langues vivantes, 72(4), 530-549. doi: 10.3138/cmlr.3306 
Statistics Canada (2016). Linguistic diversity and multilingualism in Canadian homes. Retrieved from http://www12.statcan.gc.ca/census-recensement/2016/as-sa/98-200-x/2016010/98-200x2016010-eng.cfm

Taylor, S. K., \& Snoddon, K. (2013). Plurilingualism in TESOL: Promising controversies. TESOL Quarterly, 47(3), 439-445. doi: 10.1002/tesq.127 